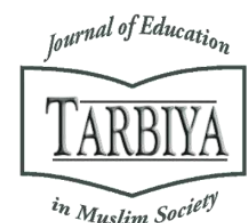

Available online at TARBIYA: Journal of Education in Muslim Society Website:

http://journal.uinjkt.ac.id/index.php/tarbiya

TARBIYA: Journal of Education in Muslim Society, 8(1), 2021, 66-81

\title{
HUMANIZING ISLAMIC RELIGIOUS EDUCATION IN BALI DURING THE COVID-19 PANDEMIC
}

\author{
Fajri Zulia Ramdhani*, Rusmayani, Kurniawati \\ STAI Denpasar Bali, Indonesia \\ E-mail: zulia@staidenpasar.ac.id
}

Received: $28^{\text {th }}$ April 2021; Revised: $27^{\text {th }}$ May 2021; Accepted: $28^{\text {th }}$ June 2021

\begin{abstract}
The delivery of Islamic Religious Education (PAI) in Bali has been fraught with difficulties, which have been exacerbated by the pandemic. This paper discusses 1) the realities of Islamic religious education in Bali, 2) the implementation of a special condition curriculum as a means of humanizing PAI education, and 3) the humanization of Islamic religious education in Bali during the COVID-19 pandemic. This research employed a qualitative phenomenological study, with data gathered through in-depth interviews with school principals, Islamic Religious Education teachers, and Muslim students' parents. The data is handled in stages that include data reduction, visualization, and verification. The findings indicate that: 1) The ratio of Islamic Religious Education teachers to pupils is imbalanced; some schools even lack Islamic Religious Education teachers, and numerous parents express dissatisfaction with online learning in PAI sessions. 2 ) Curriculum implementation for special/emergency situations; some schools have implemented it as a means of increasing learning effectiveness and efficiency, while others continue to use the national curriculum, despite teacher recognition that it is unproductive. 3) The special education curriculum is considered one of the first steps toward humanizing Religious Education Islam, which, in the face of poor online learning, must also be accompanied by teachers who are accessible to parents and students.
\end{abstract}

Keywords: online learning; tahsin; Quran reading; COVID-19; online Quran learning

\section{Abstrak}

Penyelenggaraan Pendidikan Agama Islam (PAI) di Bali penuh dengan kesulitan yang diperparah dengan adanya pandemi. tujuan dari penelitian ini adalah untuk menyelidiki penggunaan kurikulum pengaturan khusus/darurat sebagai metode memanusiakan pendidikan. Tulisan ini membahas 1) realitas pendidikan agama Islam di Bali, 2) penerapan kurikulum kondisi khusus sebagai sarana memanusiakan pendidikan PAI, dan 3) humanisasi pendidikan agama Islam di Bali pada masa pandemi COVID-19. Penelitian ini menggunakan studi kualitatif fenomenologis, dengan data dikumpulkan melalui wawancara mendalam dengan kepala sekolah, guru Pendidikan Agama Islam, dan orang tua siswa Muslim. Penanganan data dilakukan secara bertahap yang meliputi reduksi data, visualisasi, dan verifikasi. Hasil penelitian menunjukkan bahwa: 1) Rasio guru PAI terhadap siswa tidak seimbang; beberapa sekolah bahkan kekurangan guru PAI, dan banyak orang tua menyatakan ketidakpuasan dengan pembelajaran online di sesi PAI. 2) Implementasi kurikulum untuk situasi khusus/darurat; beberapa sekolah telah menerapkannya sebagai sarana untuk meningkatkan efektivitas dan efisiensi pembelajaran, sementara yang lain tetap menggunakan kurikulum nasional, meskipun diakui oleh guru bahwa kurikulum tersebut tidak produktif. 3) Kurikulum pendidikan luar biasa dianggap sebagai salah satu langkah awal untuk memanusiakan Pendidikan Agama Islam, yang dalam menghadapi pembelajaran online yang buruk, juga harus didampingi oleh guru yang dapat diakses oleh orang tua dan siswa.

Kata kunci: pembelajaran online; tahsin; membaca Al-Qur'an; COVID-19; belajar Al-Qur'an online

How to Cite: Ramdhani, F. Z., Rusmayani, Kurniawati. (2021). Humanizing Islamic Religious Education in Bali During the Covid-19 Pandemic. TARBIYA: Journal of Education in Muslim Society, 8(1), 66-81. doi:10.15408/tjems.v8i1.20636.

Permalink/DOI: http://dx.doi.org/10.15408/tjems.v8i1.20636

*Corresponding author 


\section{Introduction}

The COVID pandemic, which is still ongoing, was first confirmed in Wuhan, Hubei Province, China in December 2019. SARS-CoV-2, the virus that causes COVID-19, has spread and caused death in many countries around the world, including Indonesia. As written by CNN Indonesia (CNN Indonesia, 2020a), the first case of COVID-19 in Indonesia was announced on March 2, 2020 by the President of the Republic of Indonesia. In order to mitigate the risk of COVID-19 transmission, the Indonesian government has implemented various policies. Through a Government Circular dated March 24, 2020, the Minister of Education and Culture of the Republic of Indonesia regulates online/distance learning (Kemdikbud, 2020).

Based on a press release issued by the Coordinating Ministry for Economic Affairs HM.4.6/199/SET.M.EKON.3/08/2021 which states the extension of the Implementation of Restrictions on Community Activities (PPKM) until August 9, 2021, after previously being implemented since July 26 and extended again and again (Ekon, 2021) The regulation has an impact on the continuation of online learning at various levels of education, online learning has been implemented since March 2020 until now, August 2021.

Education, which is an urgent aspect, demands that it continues, in the midst of the outbreak of the epidemic (Azhari \& Fajri, 2021). The online-based educational process in its implementation in the field encounters various obstacles. One of them is the psychological disruption of students due to learning that lacks social interaction. Many cases that occurred during this pandemic were related to the psychological pressure experienced by students. Such as the case of a student who committed suicide in Gowa, South Sulawesi, the police suspect that this suicide was caused by the workload and poor internet network. This allegation is based on the victim's conversation with her colleague (CNN Indonesia, 2020b). Still in the same year, namely in Tangerang Regency, a student was admitted to the Mental Hospital (RSJ) due to depression.

According to a statement by the Indonesian Child Protection Commission (KPAI), the family suspects that the child is depressed because of the many online learning tasks during the Covid-19 pandemic (Callistasia Wijaya, 2021). A similar complaint was also made by Afifah Muthiah Unga Waru, a grade 10 student at SMAN 1 Soppeng, South Sulawesi. Unga complained about the imbalance in the number of assignments and deadlines given (Saifan Zaking, 2021).

To respond to various obstacles that arise, the government issued a policy by issuing a Decree of the Minister of Education and Culture of the Republic of Indonesia dated August 4, 2020, Guidelines for Implementing Curriculum in Education Units in Special Situations (Kemendikbud, 2020). The guideline states that educational units under special conditions can carry out learning by applying one of 1) still being able to refer to the national curriculum that has been implemented so far, 2) referring to the simplification of competencies set by the Head of the Research and Development Agency and Books and the Director General of Education. Vocational, or 3) simplifying the curriculum independently (Kemendikbud, 2020). Previously on 18 May 2020 the Director General of Islamic Education issued a decision on the Madrasah Emergency Curriculum Guide (Kemenag, 2020a). In one of the points it is stated that learning from home does not have to meet the demands of competence in the curriculum, but also in 
aspects of character development, noble character, ubudiyah, independence, and other social piety.

Islamic education is one of the subjects that must be studied by Muslim students. As stated by Rusmayani (Rusmayani, 2019) quoted from Law No. 20 of 2003, that every student must receive religious education in accordance with the religion he adheres to and taught by educators of the same religion. Especially for the Balinese Muslim community who are a minority. Islamic education is expected to be delivered properly and thoroughly in schools. However, online-based learning carried out during the pandemic, admitted by parents (personal interview, Guardian of Students at SMP Negeri 8 Denpasar) did not deepen their understanding of Islamic education. According to him, online learning actually confuses him, who does not have a good understanding of religion.

Islamic Religious Education in Bali on online learning, through author searches, is mostly done using the Whatsapp application. The teacher gives daily routine tasks that demand to be done, without providing material explanations, task directions, and reciprocal interactions.

Schools as educational institutions are expected to be able to provide understanding, explore, and develop the potential of students through the learning process. The reality is that during this pandemic, schools do not provide understanding, opportunities, and opportunities for students to develop their creativity and critical reasoning through the learning process. Passive learning activities and minimal reciprocal interaction slowly form mechanistic, verbalistic, and narrow understanding cultural habits so that they deviate from humanistic concepts and values (Widodo, 2013).

This research is entitled Humanization of Islamic Religious Education during the Covid19 Pandemic in Bali. This study discusses how the reality of the implementation of Islamic Religious Education learning in Bali during the Covid-19 pandemic is still far from humanization. Humanist education means that educational or teaching activities are not only informative but also formative (Sesfao, 2020).

Many similar studies that discuss education during a pandemic have been carried out, including research by Wahid, et al. This study specifically mentions fiqh subjects and their relation to students' learning interest in distance learning (Wahid, A. Hamid, et al, 2021). To the author's knowledge, research related to Islamic Religious Education in general has not been carried out. Wahid, et al discuss specifically how the urgency of fiqh in life, and its relationship with students' interest in learning in online learning. Furthermore, research conducted by Ucup Supriatna (Supriatna, 2021). Supriatna discussed how to implement the madrasa emergency curriculum policy from the Decree by the Indonesian Ministry of Religion. The research was conducted on teachers of Madrasah Ibtidaiyah in Ketapang Regency.

Budi Azhari and Iwan Fajri conducted a research in Aceh Province with the title Distance learning during the COVID-19 pandemic: School closure in Indonesia (Azhari \& Fajri, 2021). This research focuses on the introduction of distance learning, the obstacles faced by teachers, and approaches to overcome the various obstacles in the implementation of distance learning. Another study conducted by Sanjaya and Rastini (Sanjaya, 2020), revealed how to implement an emergency curriculum during a pandemic in an effort to fulfill the right to education. This study 
makes a comparison between the emergency curriculum and the national curriculum. In addition, it also further analyzes the fulfillment of the right to education in the emergency curriculum.

The author explores various studies related to the implementation of the emergency curriculum during the COVID-19 pandemic. So far, there has been no research that specifically discusses the implementation of the emergency curriculum as a form of humanization of education. Especially in the lessons of Islamic Religious Education in Bali. The research conducted by the author is a new research that has never been done before.

\section{Method}

The approach used in this research is qualitative with phenomenological method, which is a method used to explore and reveal the similarity of meaning of a phenomenon of a group of individuals. In line with the notion that phenomenology is the science of symptoms or any visible things (Yusuf, 2016).

Informants are determined purposively, namely the determination of informants with certain considerations (Sugiyono, 2017). As for the informants in this study, 2 principals, and PAI (Islamic Religious Education) teachers both at the elementary school to high school levels, both at public schools and madrasas totaled 9 people, as well as 9 Muslim parents, for a total of 20 people.

Data were collected using in-depth interview techniques to reveal more about the following problems: 1) the reality of Islamic Religious Education in Bali, 2) the realization of the curriculum for special conditions in the learning pattern of Islamic Religious Education in Bali, and 3) the humanization of Islamic Religious Education during the pandemic in Bali. Bali. Interviews were conducted in two ways, namely directly (face to face) and indirectly (by phone). Given the pandemic situation that requires minimizing face-to-face activities, some interviews were conducted by telephone.

The data obtained from the interviews are processed by data reduction stages, namely the data from the interviews are selected and sorted which are important and in accordance with the problems to be studied, then display the data, namely the data from the interviews, compiled and grouped according to each focus of the problem. The final stage is verification. namely making conclusions about each focus of the problem based on cross checks with the informants and confirmed by previous research and theories relevant to the problem. Ultimately, the data is analyzed by narrative analysis.

This study aims to determine the reality of learning Islamic Religious Education in Bali during the pandemic. Furthermore, it is hoped that it can provide input to school educational institutions in Bali to be able to consider the use of special/emergency curricula as a form of humanization of education. 


\section{Results and Discussion}

\section{The Reality of Islamic Religious Education in Bali}

The province of Bali, known as the island of the gods, is an area with a Hindu majority. According to History (Mashad, 2014). Muslim communities have existed in Bali since the reign of Dalem Ketut Ngelesir (1380-1460). This means that the Muslim community in Bali has been living side by side in harmony since hundreds of years ago.

However, even though it has existed for a long time and is the largest minority in Bali, Rusmayani said (Rusmayani, 2019) that there is an imbalance in the ratio between the number of Muslim students and teachers who teach Islamic Religious Education. One informant said that he had to teach at six schools in the Karangasem area, due to the lack of Islamic religious teachers. Whereas the role of religious teachers is vital and urgent in conveying Islamic religious values and understanding. Efforts to understand and practice religious teachings are directed to overcome, among others, the low religious understanding and practice of some religious people; not yet optimal development of religious sects; lack of empowerment of religious social institutions; low quality of family development; not yet optimal religious administration services; and overcome the phenomenon of increasing radicalization and liberalization of religious understanding.

In the Regulation of the Minister of Religion Number 18 of 2020 concerning the Strategic Plan of the Ministry of Religion for the Year 2020-2024, it is stated that among future plans in improving the quality of education, one of them is religious education. Some of the things that are the focus of the ministry are strengthening basic literacy, utilizing technology, and integrating innovative learning models, improving the quality of governance and placement of educators, and improving the character of students (Kemenag, 2020b). Previously, based on the Decree of the Ministry of Religion of 2015-2019 Number 39 of 2015 (Kemenag RI, 2015), in the field of Islamic Religious Education policies were directed at improving quality. The targets that are expected to be achieved are the availability of Islamic education services in schools, improving the quality of services, and improving the quality of understanding and practicing students' religious teachings (Kemenag RI, 2015).

The strategies used include increasing the competence and qualifications of educators and Islamic religious education staff. In addition to providing scholarships and other educational assistance for teachers, increasing teacher knowledge through the Islamic Religious Education (PAI) teacher exchange program. There is also the provision of functional allowance subsidies for non-PNS PAI teachers and the provision of professional allowances for PAI teachers. In the 2017/2018 academic year, the number of PAI teachers in Bali Province is 570 teachers, consisting of 13 PAI teachers at the Kindergarten/PAUD level, 434 elementary school teachers, 82 junior high school teachers, 21 high school teachers and 21 vocational high school level teachers. 20 teachers.

The lack of PAI teachers in Bali certainly hinders not only conventional and online learning. This has an impact on the way teachers conduct online learning in PAI lessons. An unbalanced ratio between the number of students and teachers of religion can lead to a lack of personal and communal interaction by both teachers to individual students and in one class. 
Based on the narrative of one parent whose son attends a state elementary school in the Kerobokan area, that for Muslim students who attend public schools, Islamic education tends to get less attention. This is due to the fact that in one school the number of teachers of Islamic education is only one person. So if the teacher concerned is absent, then the class is vacated because there is no substitute teacher teaching. Sometimes, Islamic religious education becomes extra outside of school lessons by taking advantage of certain times resulting from discussions between teachers and students' guardians. The teaching fees paid to PAI teachers also come from the contributions of Muslim guardians at the school.

Based on research conducted by Kartini and Kristiawan (Kartini \& Kristiawan, 2019) it is stated that professional allowances affect work motivation. Work motivation has a significant effect on teacher performance. Supriatna (Supriatna, 2021) quotes Saifulloh and Darwis (Saifulloh \& Darwis, 2020) that the teacher's role is very important to manage distance learning, especially during the COVID-19 pandemic. Teachers play a role so that learning is carried out actively, innovatively, creatively, and efficiently. So to ensure this, teachers manage online learning by planning lessons, organizing learning, implementing learning, and evaluating learning.

Another problem faced by parents of private elementary schools in Denpasar is the professionalism and experience of teachers. According to him, professionalism can be seen from how the teacher pays attention to the aspirations to the opinions of students. He said that when students answered an assignment and it was deemed wrong based on the teacher's assessment, the teacher did not provide further explanation regarding the material. Furthermore, when contacted for an explanation, the teacher chose not to respond.

PAI lessons, according to the parents of students whose daughters are studying at private elementary schools in the Kerobokan area, are less prioritized and even tend to be sidelined compared to other subjects. The role of Islamic religious education teachers during online classes during the Covid-19 pandemic is only present as assigners and assessors. The teacher does not provide any explanation regarding the material so that students understand the subject matter. According to him, Islamic education is an urgent education because it deepens attitudes and character that will affect students in life.

The same thing was said by other parents from the same school, the limited learning system tends to put pressure on students and parents. This is because students are charged with various tasks that these students do not understand anything related to the context of the material. Finally, parents must play a role in explaining the material to replace the role of the teacher. However, another obstacle that arises is that not all parents have the ability to have good religious material. So that it is difficult to provide understanding to their sons and or daughters.

Learning activities should include three main activities, namely introduction, core activity, and closing (Supriatna, 2021) (Kemenag, 2020a) In the preliminary activity, the teacher greets, prays together, and greets students. The core activity contains explanations and interactions of learning materials by teachers and students. Closing is ending the lesson. Learning that uses WhatsApp tends to abandon these three main activities in learning. Parents complained about how teachers only demanded the implementation of tasks to achieve material competence. 
According to Gunawan (Gunawan, 2021) in responding to stuttering or being unresponsive to online learning, it is necessary to fulfill the following components, namely: a stable internet network, capable electronic equipment, both mobile phones or computers, user friendly applications, efficient online socialization or learning, effective, continuous, and integrative. This means that not only tools are important requirements to fulfill online learning, but also the learning process carried out by teachers to students.

In general, education aims to help humans present their full human existence (Ramadan, 2007). If students, especially in Islamic education, are presented with learning methods that only fulfill the formality of doing assignments, without theoretical explanations, a communicative dialogical understanding process, finally education is just a formality of activities that do not fulfill its objectives.

\section{Realization of Special Condition Curriculum as a Form of Humanization of PAI Education in Bali}

The impact of the Covid 19 pandemic that hit Indonesia, especially in the field of education, was quickly responded by the Minister of Education and Culture of the Republic of Indonesia through Decree Number 719/P/2020 concerning Guidelines for Implementing Curriculum in Education Units in Special Conditions. This policy provides wider space for schools to choose and sort out the right curriculum to be used during the pandemic. The goal is to lighten the burden of student learning and the burden of teaching teachers. There are 3 options contained in the policy, namely (1) continuing to refer to the national curriculum, (2) using an emergency curriculum, and (3) simplifying the curriculum independently (Kemendikbud, 2020). Implementation of the policy in the field, most schools implement an emergency curriculum, namely a curriculum used in special conditions prepared by the Ministry of Education and Culture in the form of a simplification of the national curriculum. In the curriculum, basic competencies are reduced for each subject so that teachers and students can focus on essential competencies and prerequisite competencies for continuing learning at the next level (Kemendikbud, 2020).

The Ministry of Religion through the Director General of Islamic Education also responded to the COVID-19 pandemic by issuing Decree No. 2791 of 2020 concerning Emergency Curriculum Guidelines for Madrasahs (Kemenag, 2020a). There are five points mentioned regarding the emergency curriculum concept, namely (1) the implementation of a different emergency curriculum referring to the condition of the madrasa, (2) madrasas make modifications and innovations to the curriculum according to conditions and needs, (3) students must continue to receive educational services, (4) does not have to meet the demands of competence but emphasizes character development, noble character, ubudiyah, independence, and other social piety, (5) the emergency curriculum only applies in times of emergency.

SD Muhammadiyah 2 Denpasar Barat, is one of the Islamic religious schools where all teachers and students are Muslim (Dapodik, 2020). In accordance with the Decree of the Ministry of Education and Culture Number 719/P/2020 concerning Guidelines for Curriculum Implementation in Education Units in Special Conditions, this school chose to use an emergency curriculum that had been prepared by the Ministry of Education and Culture. The curriculum is 
considered simpler. Prior to socialization, this curriculum was discussed through a meeting with the teacher council, committee and education stakeholders.

One of the implementations of the emergency curriculum at SD Muhammadiyah 2 Denpasar Barat is to reduce the student's learning load by cutting lessons which in normal situations are 45 minutes to 30 minutes. As for the basic competencies that are theoretical in nature per material, the basic competencies that lead to practicum are prioritized. Online learning is carried out according to the lesson schedule and teachers will report the problems experienced each week in writing and verbally to the principal through the vice principal. An evaluation is carried out monthly by summoning students who have problems in learning.

SD Muhammadiyah 2 has implemented planning, organizing, actuating, and evaluating in its learning process. The implementation of the special conditions curriculum is intended not only to reduce the burden on students in fulfilling competencies but also to support the effectiveness and efficiency of learning. SD Negeri 6 Sumerta, East Denpasar is led by Mrs. Ni Made Suhartini, with a total of 42 Muslim students in this school (Dapodik, 2020). During the pandemic period, this school used a curriculum with special conditions, so all teachers, including PAI teachers, made lesson plans according to the curriculum. The learning process is carried out online.

Another school that implements an emergency curriculum is MI-Al Ma'ruf Denpasar. Teaching planning all adjusts the curriculum. Such as the use of a single sheet of Learning Implementation Plan (RPP), for one RPP contains only one basic competency (KD), and the reduction of lesson hours to 30 minutes.

SD Negeri 6 Sumerta mentioned several obstacles encountered by the school, namely the lack of teacher skills in carrying out online learning such as operating zoom, making learning videos, and making questions using google forms. Significant and sudden changes related to pandemic conditions, of course, make teachers not fully prepared for online learning. The teaching experience of teachers is less relevant to online learning, (Azhari \& Fajri, 2021) because online learning requires the operation of applications to support learning. While the experience of teachers so far was born from conventional-based learning experiences and scientific materials. Thus, training on the use of applications for online learning should be intended for teachers.

The use of special conditions curriculum is used by SD Alam Mushroom, all teachers and students in this school are Muslim. In its implementation, maximizing online learning media, using learning videos, voice notes, and google classroom for collecting assignments. Before teaching, teachers are required to make an emergency lesson plan (RPPD) and finish teaching a daily work report (LKH).

The problem experienced by teachers in online learning is that students are often late in submitting assignments and some do not submit assignments at all, are difficult to control, and prefer to play rather than study. Although the emergency curriculum has been implemented, its implementation has not been optimal. An alternative that can be done is to organize PAI learning with blended learning with a note that the school is in a safe zone and conduct programmed home visits to students. 
Learning with a blended learning model that combines face-to-face learning and online learning, as well as the application of home visit learning is very helpful for teachers to obtain information about the obstacles experienced by students and parents during distance learning (Supriatna, 2021). The visit or home visit program carried out by teachers during the pandemic is a form of teacher attention to students, when teachers find their students are rarely active when online learning or rarely collect assignments, in addition to asking through WhatsApp groups or telephones, it would be better if the teacher met the student to find out the immediate condition of the student, the study showed that the implementation of home visits had a positive effect on student learning outcomes by $96 \%$ (Lukinah, 2021).

In contrast to schools that implement special conditions or emergency curricula, there are schools that continue to use the national curriculum. Among them is SD 18 Padangsambian, West Denpasar. The number of students who are Muslim is 53 people (Dapodik, 2020). In completing the material referring to the basic competencies in the national curriculum, learning is carried out through whatsapp and google form.

The obstacles encountered at SD 18 Padangsambian during online learning were internet signals, and the decline in students' learning motivation. Problems related to internet signals and the use of technology are common problems that pose challenges in online learning. Teachers must provide positive encouragement and encouragement to students in dealing with online learning. In this case, teachers should also pay attention to their psychological condition and wellbeing (Güvercin et al., 2021) citing (OECD, 2020), (WHO, 2020), (UNESCO, 2020).

Furthermore, at the junior high school level that applies the special/emergency condition curriculum, SMP Harapan Kristian, with a total of 101 Muslim students. (Dapodik, 2020) The implementation of this curriculum is directed by the principal through the vice principal in the curriculum field to the teacher council. Then the teacher passes the information on the adjustment of the implementation of this curriculum to the students. One proof of the implementation of this curriculum is to reduce the burden of student learning through trimming basic competencies, for grades VII and VIII it reduces 1 basic competency, for class IX reduces 2 basic competencies. During online PAI learning, the teacher uses power points, learning videos to deliver practical material such as wudu material, funeral prayers and so on. For assignments given to students, the teacher gives a deadline the next day to collect.

Another junior high school chooses to implement the national curriculum, namely the SMP Bintang Persada Tabanan, which has 93 Muslim students at this school (Dapodik, 2020). The PAI learning process in this school is less effective because PAI lessons are conducted outside of class hours. So that religious teachers only come during teaching hours. During the pandemic, this school continues to use the national curriculum on the grounds that it is still possible for the secondary school level to complete all basic competencies. The same thing also happened at SMP PGRI 2 Denpasar and SMPN 8 Denpasar, both carried out lessons outside effective lesson hours. For the number of Muslim students at SMP PGRI 2 Denpasar, 81 people, and at SMPN 8 Denpasar 31 people. The two schools are taught by the same teacher, Nur Cahyati, who is a final semester student at STAI Denpasar Bali.

The implementation of the national curriculum that is deemed ineffective, even by PAI teachers as facilitators, should be taken into consideration and evaluation. Schools must review 
the efficiency and effectiveness of the national curriculum in online learning. Considering that online and conventional learning are in different conditions. The emergency curriculum is designed as an option for school policy in carrying out learning. The emergency curriculum simplifies the national curriculum by sorting out the urgent competencies for students. So that teachers and students are not charged with completing all competencies from the National Curriculum (Sanjaya, 2020).

SMP PGRI 2 Denpasar and SMPN 8 Denpasar do not apply the emergency curriculum. PAI learning uses whatsapp which is sometimes interspersed with zoom. The duration of learning per level is only 35 minutes, while competence still refers to the national curriculum. However, in reality many competencies are not achieved due to ineffective study time, insufficient duration of study time and online learning.

Junior high school students who are older than elementary school students need a different approach. The approach taken must remain based on the uniqueness and distinctiveness of students, develop skills, opportunities, abilities, promote self-awareness, self-determination, selfrealization and self-affirmation, and to restore self-esteem (Sakun A.V, 2021). Although learning is done online, it is hoped that this approach will not deviate from the educational process.

Bintang Persada Junior High School Tabanan conducts PAI lessons in turns, the first week through learning videos and whatsapp groups for discussion sessions, then the following week giving assignments with a deadline of 2-3 days for collection. The implementation of online learning, especially outside effective hours, adds to the ineffectiveness of PAI learning, this can be seen from some students who do not collect assignments at the specified time. With these limitations, teachers can make learning variations that emphasize interaction (Supriatna, 2021). Teachers must support students and direct them to always maintain interest in learning. Active participation, student involvement in learning can arouse student interest in online learning.

Teachers during the pandemic must be able to transform into humanist educators, not burdening students with homework assignments (Syah, 2020) but the learning that is carried out must provide more space for students. The implementation of the emergency curriculum used by the school must be communicated with parents, so that they understand and can become good relations for teachers in educating students at home, as for the sign of success in the application, namely students feel comfortable and excited in the PAI learning process at home (Asfiati, 2020).

Implementing the emergency curriculum properly will provide space for teachers and students to focus on essential competencies, teachers are not burdened with the demands of completing the national curriculum, and students are not burdened with many basic competencies that must be completed, during a pandemic, students should be directed to develop their potential, giving daily tasks and assessing students based on the assignments given by the teacher should be avoided, because the implementation of the emergency curriculum actually makes it easier for teachers and students, and humanizes humans, namely leading students to be able to think freely and creatively, in fact students and teachers are both subjects in the teaching and learning process. and the object is the material or science that is studied together (Larasati, 2020). 
The implementation of the national curriculum should not ignore the conditions and needs of teachers and students. The government through the Ministry of Education and Culture of the Republic of Indonesia and the Ministry of Religion provides flexibility to schools to regulate, compile, and adjust the curriculum. Schools should take advantage of this to increase the effectiveness of learning. So that learning objectives and competencies can be achieved properly and optimally.

\section{Humanization of Islamic Religious Education during the Covid-19 Pandemic in Bali}

Education is a basic right for every Indonesian citizen, this is stated in the Indonesian Constitution article 31 paragraph 1 which reads "Every citizen has the right to education". (Constitution of the Republic of Indonesia 1945) Education is a process of empowering a person to become a more civilized human being and with a strong character based on the values of Pancasila. Education should be able to shape a person to become a wiser and noble human being. However, in reality, there are still many educational practices that shackle students through regulations imposed by schools.

The essence of education is as a process of humanizing humans (humanization), which often does not materialize because it is trapped in the destruction of human values (dehumanization). (Musthofa, 2020) This is due to differences in the concept of implementation with existing rules in educational institutions. This gap causes the ideals of the Indonesian Constitution Article 31 paragraph 1 which has a mission to raise human dignity through education to be said to have not been achieved. This mission has not been achieved because education in Indonesia has not been able to humanize students.

This condition can also be called the Banking Model as expressed by Paulo Freire in Pedagogy of the Oppressed (Justin, 2018) namely the symptoms of teachers as depositors who send knowledge to empty banks (students) that must be filled. Students are positioned in absolute ignorance that has no creative power at all. Education is only a saving activity, there is no communicative dialogue going on. The teacher only conveys statements that are required to be accepted and memorized and repeated by students. Students are only taught to receive, record, memorize, and store. (Sesfao, 2020)

Paulo Freire mentions that the things that must be contained in liberating education are that they must be dialogical and communicative. (Sesfao, 2020) One-way learning, the teacher as the sole subject of education is not a liberating education. Students are forced to accept knowledge by the teacher without adequate dialogue to further analyze understanding. Communicative dialogue means that the teacher views students as whole human beings who have common sense, opinions, and perspectives.

The online learning that occurs, based on the experience told by the parents above, students are not only piggy banks who are ready to receive knowledge and memorize only. Online learning is then only limited to giving assignments without an adequate understanding or explanation at all. That is, online learning in a pandemic condition, is not even able to maintain the condition of providing unidirectional understanding, but instead abandons it.

Education should not only be a means of transferring knowledge between teachers and students, but education must function so that students can re-explain the knowledge they have 
acquired so that they can be implemented in life (Sesfao, 2020), Sakun, et al (Sakun A.V, 2021) state that education must be built based on structure of the reality of life, because humans are the center of life.

Giving routine assignments with the hope that students read the material in books independently, without an explanation of knowledge will not have been impactful on life. In line with this, Ki Hajar Dewantara believes that educational or teaching activities should not be limited to informative but also formative actions. Informative means that education becomes an activity to build intellectual autonomy, which has an impact on cognitive intelligence (Sesfao, 2020).

Abdul Munir Mulkhan, as quoted by Zainuddin, said that education should ideally be carried out in the name of students' interests. Not referring to the interests of teachers, rulers, and managers. Education as a transfer of knowledge, values, and work skills is not considered a wise and realistic view (Azhari \& Fajri, 2021). Education and the process are not only about fulfilling the obligations of teachers to formal institutions and managers, learning activities must be carried out with the sincerity of the teacher so that students can understand and achieve the expected competencies.

The reduction of basic competencies, as stated in the regulation in the author's view, can be a solution that the government can do regarding the learning burden on competencies that are considered burdensome. Even though the curriculum for special circumstances is enforced, without the seriousness of teachers presenting themselves in communicative dialogue, the humanization of education will not occur.

Despite the many limitations on online learning. It should not prevent the teacher from opening a communicative dialogic classroom to students. Students are only charged with fulfilling tasks on worksheets that must be completed within a certain time. Students compete to complete as necessary and as soon as possible for the sake of a good assessment of the fulfillment of the task, as a result, students' humanity and learning rights that must be fulfilled are neglected.

Islamic religious education as urgent learning is seen as less important and even unpleasant. Qodri Azizy argues as quoted by Ayu Wilatika this is due to several things, such as (Wilatikta, 2020): 1) Islamic teaching tends to focus on memorization, while the urgency of Islam is on practice; 2) Islamic religious education tends to be a formality with a theological paradigm alone; 3) Reasoning and argumentation receive less priority in learning interactions; 4) Appreciation of Islamic religious values is not prioritized; 5) Lack of attention to the arrangement of the learning environment of the Islamic Religious Education process; 6) Lack of depth in Islamic teaching methods.; 7) The benchmark for achieving Islamic religious education is only formality; 6) Success in Islamic education has not become a standard of progress for other subjects.

Abdul Munir Mulkhan stated that the principle that must be held primarily in Islamic religious education is that the series of learning must be enriched with divine experience. Not merely as a socialization or internalization of knowledge, and guiding students to experience the divine experience for themselves that must be done throughout their lives. (Zainuddin, 2020) Of course, this process cannot exist independently through assignments that are sent and must be 
completed immediately, or through homework that accumulates and must be submitted. Instead, it comes from the form of intimate communicative dialogue between students and teachers.

In addition to two-way communication between teachers and students, there is also a need for communication between teachers and parents. Parents can help humanize students as whole individuals who are able to provide opinions and attitudes in the educational process. Parents no longer play a role in completing children's tasks without involving them. But it needs a free communicative dialogue to build a joint discussion on how knowledge can be internalized and even present as a religious experience.

Internalization of Islamic education can be done in various ways. To improve understanding of the material, the teacher can open a discussion room regarding students' understanding of the topic of knowledge. Bringing students together with the reality of the diversity of knowledge in their families. Furthermore, students were asked to internalize the value of knowledge into simple practices such as worship rituals, the practice of helping others, and others. So that students are able to understand that Islam is not just a matter of memorization, but daily application.

\section{Conclusions}

Based on the results of the research above, it can be concluded that the reality of Islamic Religious Education (PAI) in Bali is the lack of PAI teachers. There is a gap between the ratio of Muslim students and the number of teachers teaching PAI. Many parents complain about online learning in PAI lessons regarding the lack of attention from teachers, and teachers who do not provide explanations about the material, and only give assignments. Regarding the implementation of the curriculum for special/emergency conditions, several schools have implemented it as a form of learning effectiveness and efficiency.

Meanwhile, some schools still choose to implement the national curriculum, even though it is recognized by teachers as being ineffective and unachievable. It is hoped that the curriculum for special conditions can be a step forward in the implementation of the humanization of Islamic Religious Education. In the midst of ineffective online learning and only giving assignments. However, the implementation of the curriculum for special conditions must be accompanied by teachers who open up a communicative dialogue space between students and parents.

\section{References}

Asfiati, P. I. (2020). Figur Pendidik Humanis Di Masa Pandemi Covid 19. 12(2), 23-34.

Azhari, B., \& Fajri, I. (2021). Distance learning during the COVID-19 pandemic: School closure in Indonesia. International Journal of Mathematical Education in Science and Technology. https://doi.org/10.1080/0020739X.2021.1875072

Callistasia Wijaya. (2021). Covid-19: "Stres, mudah marah, hingga dugaan bunuh diri", persoalan mental murid selama sekolah dari rumah. https://www.bbc.com/indonesia/indonesia-55992502 
CNN Indonesia. (2020a). Jokowi Umumkan Dua WNI Positif Corona di Indonesia. Cnnindonesia.Com. https://www.cnnindonesia.com/nasional/20200302111534-20479660/jokowi-umumkan-dua-wni-positif-corona-di-indonesia

CNN Indonesia. (2020b). Korban-korban PJJ, Buah Simalakama Pendidikan di Masa Pandemi. https://www.cnnindonesia.com/nasional/20201025032144-20-562424/korban-korban-pjjbuah-simalakama-pendidikan-di-masa-pandemi

Dapodik. (2020). Data Pokok Pendidikan. In Kementerian Pendidikan dan Kebudayaan.

Ekon. (2021). Pemerintah Perpanjang PPKM Level 4 sampai 9 Agustus 2021. Ekon.Go.Id. https://ekon.go.id/publikasi/detail/3188/pemerintah-perpanjang-ppkm-level-4-sampai-9agustus-2021

Gunawan. (2021). Upaya Meningkatkan Guru pada Kurikulum Darurat Covid-19 Melalui Pelaksanaan Supervisi Akademik Berbantuan Zoom Meeting di SMAN 3 Sidrap dan SMAN 9 Sidrap. EduPsyCouns Journal, 3, 1-14.

Güvercin, D., Kesici, A. E., \& Akbașlı, S. (2021). Distance Education Experiences of TeacherParents during the COVID-19. Athens Journal of Education, 1-21. https://www.athensjournals.gr/education/2021-4145-AJE-Kesici-05.pdf

Justin, D. (2018). Pedagogy of the Oppressed. LitCharts LLC.

Kartini, D., \& Kristiawan, M. (2019). Pengaruh Tunjangan Profesi dan Motivasi Kerja Terhadap Kinerja Guru. Kelola: Jurnal Manajemen Pendidikan, 6(1), 25-33. https://doi.org/10.24246/j.jk.2019.v6.i1.p25-33

Kemdikbud. (2020). SURAT EDARAN MENDIKBUD NO 4 TAHUN 2020 TENTANG PELAKSANAAN KEBIJAKAN PENDIDIKAN DALAM MASA DARURAT PENYEBARAN CORONA VIRUS DISEASE (COVID- 1 9) - Pusdiklat Pegawai Kementerian Pendidikan dan Kebudayaan. In Https://pusdiklat.kemdikbud.go.id/.

Kemenag. (2020a). Keputusan Direktur Jenderal Pendidikan Islam Nomor 2791 Tahun 2020 Tentang Panduan Kurikulum Darurat Pada Madrasah. Kemenag.Go.Id.

Kemenag. (2020b). Peraturan Menteri Agama Republik Indonesia Nomor 18 Tahun 2020 Tentang Rencana Strategis Kementerian Agama Tahun 2020-2024. Kemenag.Go.Id.

Kemenag RI. (2015). Keputusan Menteri Agama Republik Indonesia Nomor 39 Tahun 2015 Tentang Rencana Strategis Kementerian Agama Tahun 2015- 2019. Keputusan Menteri Agama Republik Indonesia, 39, 1-143.

Kemendikbud. (2020). Kepmendikbud Nomor 719/P/2020 tentang Pedoman Pelaksanaan Kurikulum pada Satuan Pendidikan dalam Kondisi Khusus. Www.Kemdikbud.Go.Id, 022651, 9. https://www.kemdikbud.go.id/main/blog/2020/08/kemendikbud-terbitkankurikulum-darurat-pada-satuan-pendidikan-dalam-kondisi-khusus

Larasati, D. (2020). Pendidikan Humanis Paulo Freire Dalam Perpektif Pendidikan Islam. Faculty of Tarbiya and Teaching Sciences Repository. https://doi.org/10.33096/jiir.v17i2.84 
Lukinah, I. (2021). The effect of home visit on the learning outcomes of class 3 students in SD IQ Al-Islam. Journal of Educational Research, 1(4), 128-134.

Mashad, D. (2014). Muslim Bali: Mencari Kembali Harmoni yang Hilang. Pustaka Al-Kautsar.

Musthofa. (2020). Humanisasi PPendidikan Pesantren. Rajawali Press.

OECD. (2020). A framework to guide an education response to the COVID-19 Pandemic of 2020. Oecd-Ilibrary.Org. https://read.oecd-ilibrary.org/view/?ref=126_126988t63lxosohs\&title=A-framework-to-guide-an-education-response-tothe-Covid-19-Pandemicof-2020.

Ramadan, W. (2007). Perspektif Humanisasi Pendidikan Dalam Konteks Ke-Islam-An Dan KeIndonesia-An (Upaya Rekonstruksi Perspektif Pendidikan Berbasis Humanis, Unggul dan Islami) Oleh. 1-13. https://www.academia.edu/4934215/ PERSPEKTIF_HUMANISASI_PENDIDIKAN_DALAM_KONTEKS_KE-ISLAMAN_DAN_KE-INDONESIA-AN?auto=download

Rusmayani. (2019). Potret Pembelajaran PAI dan Budi Pekerti pada Sekolah Menengah Umum di Bumi Minoritas. Proceedings of Annual Conference for Muslim Scholars, Volume $3 \mathrm{~N}$. http://proceedings.kopertais4.or.id/index.php/ancoms/article/view/268

Saifan Zaking. (2021). Curhatan Siswa yang Alami Kesulitan di Masa Pandemi Covid-19. https://www.jawapos.com/nasional/pendidikan/08/01/2021/curhatan-siswa-yang-alamikesulitan-di-masa-pandemi-covid-19/

Saifulloh, A. M., \& Darwis, M. (2020). Manajemen Pembelajaran dalam Meningkatkan Efektivitas Proses Belajar Mengajar di Masa Pandemi Covid-19. Bidayatuna: Jurnal $\begin{array}{llll}\text { Pendidikan Guru Mandrasah } 285 . & \text { Ibtidaiyah, }\end{array}$ https://doi.org/10.36835/bidayatuna.v3i2.638

Sakun A.V, K. T. . (2021). Sakun A . V ., Doctor of Philosophy, Associate Professor , Head of the Department of Philosophy, Political Science and Ukrainian Studies Kyiv National University of Technologies and Design Kadlubovich T . I ., Candidate of Sociological Sciences , Associ. International Scientific Conference Sakun, 155-158.

Sanjaya, J. B. (2020). Implementasi Kurikulum Darurat di Masa Pandemi COVID-19 Dalam Upaya Pemenuhan Hak Pendidikan. Journal of Indonesian Law (JIL), 1(2), 14. https://doi.org/10.18326/jil.v1i2.161-174

Sesfao, M. (2020). Perbandingan Pemikiran Pendidikan Paulo Freire Dengan Ajaran Tamansiswa Dalam Implementasi Merdeka Belajar. Prosiding Seminar Nasional, 261-272.

Sugiyono. (2017). MetodePenelitian Kuantitatif, Kualitatif dan R\&D. Bandung: PT Alfabet. In Sugiyono. (2017). MetodePenelitian Kuantitatif, Kualitatif dan R\&D. Bandung: PT Alfabet.

Supriatna, U. (2021). Implementasi Kebijakan Kurikulum Darurat Madrasah. Ta'Limuna, 10(01), 42-54. https://e-journal.staima-alhikam.ac.id/talimuna/article/view/594/352 
Syah, R. H. (2020). Dampak Covid-19 pada Pendidikan di Indonesia: Sekolah, Keterampilan, dan Proses Pembelajaran. SALAM: Jurnal Sosial Dan Budaya Syar-I, 7(5). https://doi.org/10.15408/sjsbs.v7i5.15314

UNESCO. (2020). COVID-19 Educational Disruption and Response. Unesco.Org. https://en.unesco.org/covid19/educa tionresponse

Wahid, A. Hamid, D. (2021). Problematika pembelajaran fiqih terhadap minat belajar siswa dalam pembelajaran jarak jauh. Edureligia, 05(01), 1-17.

WHO. (2020). Mental health and Psychological Resilience during the COVID-19 pandemic. Euro. Who.Int.

Widodo, H. (2013). Pendidikan: Humanistik atau Dehumanisasi. https://pgsd.uad.ac.id/2014/01/23/pendidikan-humanisasi-ataudehumanisasi/\#: - :text=Humanisasi dan dehumanisasi adalah dua,pemberdayaan masyarakat melalui ilmu pengetahuan.

Wilatikta, A. (2020). Manajemen Kurikulum Pendidikan Agama Islam Jenjang Pendidikan Dasar: Kontekstualisasi Strategi Pembelajaran Semasa Pandemi. Jurnal Ilmu Agama Islam, $1-12$.

Yusuf, M. A. (2016). Metode Penelitian Kuantitatif, Kualitatif I\& Penelitian Gabungan. Prenada Media. https://books.google.co.id/books?id=RnA-DwAAQBAJ

Zainuddin, F. M. (2020). "Abdul Munir Mulkhan, Paradigma Intelektual Muslim Pengantar Filsafat Pendidikan Islam dan Dakwah.” IAIN Madura. 